S4-Accredited - SK No. 85/M/KPT/2020
Journal Page is available at http:/www.jurnalpeternakan.unisla.ac.id/index.php/ternak/index

\title{
Preservation of Spermatozoa Sumba Ongole Bulls Using Citrate Yolk Diluent with the Addition of Palmyra Palm Juice
}

\author{
Anita Tamu Ina a, Alexander Kaka ${ }^{b}$ \\ $a, b^{*}$ Department of Biology Education, Faculty of Social Sciences, Wira Wacana Christian University Jl. R. Soeprapto Street.35 Waingapu, \\ East Nusa Tenggara, Indonesia \\ $b^{*}$ Department of Animal Husbandry, Faculty Of Science And Technology Wira Wacana Christian University Jl. R. Soeprapto No.35 \\ Waingapu, East Nusa Tenggara, Indonesia \\ *email:alexkaka@unkriswina.ac.id
}

\section{A R T I C L E I N F O}

Article history:
Received 01 Nopember 2020
Revised 15 Nopember 2020
Accepted 21 Desember 2020
Available online 31
Desember 2020

\section{Keywords: \\ Semen, \\ Egg Yolk Citrate, \\ Palm sap, \\ Preservation, \\ Sumba ongole}

\author{
IEEE style in citing this \\ article: \\ A.T.Ina and A. Kaka, " \\ Preservation of spermatozoa \\ Sumba Ongole Bulls Using a \\ citrate yolk diluent with the \\ addition of palmyra palm \\ juice," Jurnal Ternak \\ Universitas Islam \\ Lamongan, vol. 11, no. 2 , \\ pp. $86-90,2020$
}

\section{A B S T R A C T}

The purpose of this study was to determine the quality of the ability of spermatozoa cells to maintain the use of a yolk citrate (YC) diluent with the addition of palmyra palm juice during preservation. The material used for this research was 2 Sumba Ongole bulls as a source of semen. Semen was collected by using an artificial vagina that is processed twice a week. The obtained semen was macroscopically analyzed, including volume, colour, consistency, $\mathrm{pH}$ and smell. Meanwhile, microscopic evaluation includes mass movement, motility, concentration, viability and abnormalities. The semen showed $>75 \%$ motile sperm divided into four treatments and dilute each with $\mathrm{YC}\left(\mathrm{P}_{0}\right), 95 \% \mathrm{YC}+5 \%$ palmyra palm juice (PPJ) (P1), 90\% YC+10\% PPJ $\left(\mathrm{P}_{2}\right), 85 \% \mathrm{YC}+15 \% \mathrm{PPJ}$ and each was stored at $3-5^{\circ} \mathrm{C}$. The results of statistical analysis showed that $\mathrm{P} 0, \mathrm{P} 1$ treatments were significantly different $(\mathrm{P}<0.05)$ between $\mathrm{P} 2$, P3 from day 0 to day 4 of storage. The addition of palmyra palm did not affect the motility of spermatozoa, but had a positive effect on the viability of spermatozoa with the addition of $5 \%$ palm sap during storage for 4 days at a temperature of $3-5{ }^{\circ} \mathrm{C}$.

Jurnal Ternak (Animal Science Journal) Faculty of Animal science - Lamongan Islamic University) with CC BY NC SA license.

\section{Introduction}

Spermatozoa preservation is an effort to maintain the quality of spermatozoa Sumba Ongole (SO) bulls. Preservation is carried out to maintain the quality of spermatozoa in order to support the application of technology artificial insemination (AI). The success of AI depends on the quality of semen, inseminator factors, female acceptors and the accuracy of detection of estrus as well as step to maintain semen quality after storage. Fresh semen does not last long in vitro storage, even the use of fresh semen at a temperature of 25-27 $\mathrm{C}^{0}$ should not be more than 3 hours [10]. Meanwhile, according to [8], the requirements for semen diluent materials must contain elements similar to the physical, chemical properties of spermatozoa and not be toxic to spermatozoa and the reproductive organs of female livestock. Seeing the requirements of this diluent allows the use of egg yolk citrate diluent as a SO bulls semen diluent which functions as a buffer, to maintain osmotic pressure and electrolyte balance. 
Concurrently, palm juice is a source of carbohydrates such as sucrose, glucose and fructose which function as cryoprotectant energy for spermatozoa cells. In Addition, according to [4], reported that palmya palm juice contains relatively high sugar, namely $10 \mathrm{~g} / 100 \mathrm{~mL}$.

According to [14], sugar is a source of extracellular cryoprotectants that protect cells from outside and is used for semen preservation at low temperatures. Conversely, [16] stated that fructose is the basic sugar as an excellent source of energy for spermatozoa through the fructoliasis process. The use of palmyra palm juice as a semen diluent for SO has not been widely reported, whereas palmyra palm juice has the potential to be used as a semen diluent, easy to obtain and relatively inexpensive. This study aims to determine the motility and survival of SO bulls spermatozoa in yellow citrate diluent with the addition of palmyra palm juice with a temperature of $3-5^{\circ} \mathrm{C}$.

\section{Results and Discussion}

\section{Characteristics of Fresh Semen SO bulls}

The characteristics of fresh semen obtained from SO bulls were evaluated macroscopically and microscopically. The results of the semen evaluation can be used as a for dilution according to treatment to determine the motility and viability of the spermatozoa of $\mathrm{SO}$ bulls during storage. The data on the characteristics of fresh semen can be seen in table 1 below.

Table 1. Characteristics of Fresh Semen Sumba Ongole bulls

\begin{tabular}{cll}
\hline Assessment & Parameters & Mean \pm SD \\
\hline & Semen volume $(\mathrm{mL})$ & $4.5 \pm 0.89$ \\
& Consistency & $\begin{array}{l}\text { medium category- } \\
\text { thick }\end{array}$ \\
Macroscopically & Colour & Creamy white \\
& $\mathrm{pH}$ & $6.76 \pm 0.12$ \\
& Smell & Typical bulls SO \\
\hline & Mass activity & +++ \\
& Sperm motility $(\%)$ & $78.75 \pm 3.93$ \\
Microscopically & Sperm concentration $\left(10^{6} / \mathrm{cc}\right)$ & $1696.95 \pm 525.99$ \\
& Live sperm $(\%)$ & $78.95 \pm 3.31$ \\
& Sperm abnormalities $(\%)$ & $14.90 \pm 2.63$ \\
\hline
\end{tabular}

The results showed that the average volume of semen Sumba Ongole bulls was in the normal category, namely the volume reached $4.05 \pm 0.89 \mathrm{ml}$ /ejaculate. The volume obtained in this is lower when compared to the results of the study by [12] which obtained a volume of $5 \mathrm{ml} /$ ejaculate. Simultanously, the research results reported by [15] showed that the volume of semen was only 2.26 $\mathrm{ml} /$ ejaculate. The color of SO bulls semen obtained in this study is creamy white. Semen color is generally milky white or creamy due to the presence of riboflavin which has autosomal recessive properties [16]. Concurrently, the consistency achieved is in the medium category- thick. The average $\mathrm{pH}$ obtained was $6.76 \pm 0.12$ with a typical SO cow odor. This result is low when compared to the results of the study by [2] with an average $\mathrm{pH}$ of 6.85 . In general, the $\mathrm{pH}$ of semen in the normal category ranges from 6.4 to 7.8 [5]. Based on the results of the macroscopic evaluation, cement is suitable for further evaluation at the microscopic evaluation stage.

The results of microscopic evaluation of SO bulls semen showed mass activity ranging from +++ , which means that the quality of the cement was good because of the thick waves shaped like thick black clouds, actively and quickly moved. Conversely a study by [12] found that the mass movement 
of ongole cattle was +++. The average motility obtained was $78.75 \pm 3.93 \%$. This result is higher than the results of research by [13] with motility reaching $65.46 \%$. Even so, the average motility of the results of the study was in the good category. According to [16] which states that the motility of fresh semen beef cattle ranges between $70-90 \%$. The viability obtained in this study reached $78.95 \pm 3.31 \%$. The results of this study are low compared to the results of the study by [12] which obtained a viability of $86.5 \%$, but higher than the results of the study by [15], namely the viability was obtained $73.70 \%$.

The Sperm abnormalities reach $14.90 \pm 2.63 \%$. This result is higher when compared to the results of the study by [15] which obtained abnormalities of $7.40 \%$. The level of abnormality obtained in this study is still in the good category. According to [5], the abnormal level of spermatozoa should not exceed $20 \%$. The concentration obtained in this study was $1696.95 \times 106$ cells / ml. This result is higher when compared to the results of research by [13] which reported an average concentration of 1,079.04 cells / $\mathrm{ml}$. Even so, the semen concentration of the study results was in the normal category. According to [6], the normal average concentration of bovine spermatozoa ranges from 1000-1800 million cells / $\mathrm{ml}$. Based on the results of the macroscopic and microscopic evaluation of fresh semen from SO bulls, it can be continued at the dilution stage according to the predetermined treatment in order to determine the motility of spermatozoa after diluting with yolk citrate and palmyra palm juice.

\section{Effect of Treatment on Motility}

Motility is one indicator of the success of spermatozoa cell fertility in Sumba Ongole cattle. The research data can be described in Table 2 below.

Table 2. Percentage of Spermatozoa Motility of SO bulls at a temperature of 3-5 ${ }^{\circ} \mathrm{C}$

\begin{tabular}{ccccc}
\hline \multirow{2}{*}{$\begin{array}{c}\text { Storage Time } \\
\text { (day) }\end{array}$} & $\mathrm{P}_{0}$ & $\mathrm{P}_{1}$ & $\mathrm{P}_{2}$ & $\mathrm{P}_{3}$ \\
\cline { 2 - 5 } & $78.00 \pm 2.74^{\mathrm{a}}$ & $79.00 \pm 2.24^{\mathrm{a}}$ & $73.00 \pm 2.74^{\mathrm{b}}$ & $72.00 \pm 3.94^{\mathrm{b}}$ \\
1 & $72.00 \pm 4.47^{\mathrm{a}}$ & $73.00 \pm 2.74^{\mathrm{a}}$ & $66.00 \pm 4.18^{\mathrm{b}}$ & $65.00 \pm 5.00^{\mathrm{b}}$ \\
2 & $62.00 \pm 2.74^{\mathrm{a}}$ & $65.00 \pm 3.54^{\mathrm{a}}$ & $52.00 \pm 5.70^{\mathrm{b}}$ & $49.00 \pm 8.94^{\mathrm{b}}$ \\
3 & $55.00 \pm 5.00^{\mathrm{a}}$ & $57.00 \pm 4.47^{\mathrm{a}}$ & $46.00 \pm 4.18^{\mathrm{b}}$ & $42.00 \pm 9.08^{\mathrm{b}}$ \\
4 & $47.00 \pm 4.47^{\mathrm{a}}$ & $48.00 \pm 7.58^{\mathrm{a}}$ & $34.00 \pm 8.94^{\mathrm{b}}$ & $22.00 \pm 10.95^{\mathrm{c}}$ \\
\hline
\end{tabular}

Different superscript letters show a significant difference $(\mathrm{P}<0.05)$

Table 2 above shows the effect of treatment on spermatozoa motility of SO bulls. The results of statistical analysis showed that the motility of spermatozoa up to the ${ }^{4}$ th day of storage for treatment P1 reached $48.00 \pm 7.58 \%$, the highest compared to treatment P0; P2 and P3 respectively achieved $47.00 \pm$ $4.47 \% ; 34.00 \pm 8.94 \% ; 22.00 \pm 10.95 \%$. These results indicate that the yolk citrate diluent with the addition of palmyra palm juice was not able to maintain the quality of the cement during the storage process.

Based on the results of ANOVA analysis showed that the treatments were not significantly different $(\mathrm{P}>0.05)$ between treatments $\mathrm{P} 0, \mathrm{P} 1$ and P2, P3 from day 0 to day 4 of storage. Nevertheless, $\mathrm{SO}$ bulls spermatozoa preservation using yolk citrate diluent with the addition of pamyra palm juice can be used as a SO bulls semen diluent. This is because the composition of the diluent is more complete when compared to other diluents, namely the citrate diluent acts as a buffer source so that the degree of acidity is relatively stable. In addition, palmyra palm diluent is a source of energy for SO spermatozoa so that it is able to maintain the spermatozoa motility of Sumba Ongole cattle until the th day of storage.

For the purposes of IB, it is better to use the P1 treatment with the addition of $5 \%$ palmyra palm in yellow citrate diluent with the percentage of motility that can only last until the 4 day of storage. In P2 and P3 treatments, 10 and 15\% addition of palmyra palm in yolk citrate diluent, respectively, were only able to maintain spermatozoa motility of $\mathrm{SO}$ until the $2^{\text {nd }}$ and $1^{\text {st }}$ storage, named spermatozoa motility above $50 \%$. It is suspected that the higher the percentage of lontar sap can reduce the motility of spermatozoa because palmyra palm is acidic so that the role of citrate diluent as a buffer is unable to stabilize $\mathrm{pH}$. According to [7], an increase in $\mathrm{pH}$ can result in decreased motility and viability of 


\section{Effect of Treatment on Viability}

Viability is the ability of spermatozoa cells to survive during the storage process. Data on the effect of treatment on viability can be described in Table 3 below.

Table 3. Spermatozoa Viability of SO Bulls

\begin{tabular}{ccccc}
\hline \multirow{2}{*}{$\begin{array}{c}\text { Storage Time } \\
\text { (day) }\end{array}$} & $\mathrm{P}_{0}$ & $\mathrm{P}_{1}$ & $\mathrm{P}_{2}$ & $\mathrm{P}_{3}$ \\
\cline { 2 - 5 } & $75,18 \pm 3,25^{\mathrm{a}}$ & $78,11 \pm 3,65^{\mathrm{a}}$ & $68,92 \pm 2,72^{\mathrm{b}}$ & $63.82 \pm 2.17^{\mathrm{c}}$ \\
1 & $70,58 \pm 3,23^{\mathrm{a}}$ & $73,52 \pm 2,12^{\mathrm{a}}$ & $63,45 \pm 2,94^{\mathrm{b}}$ & $58.11 \pm 1.22^{\mathrm{c}}$ \\
2 & $64,00 \pm 3,05^{\mathrm{a}}$ & $67,86 \pm 2,57^{\mathrm{b}}$ & $53,22 \pm 1,46^{\mathrm{c}}$ & $48.67 \pm 3.34^{\mathrm{d}}$ \\
3 & $54,00 \pm 5,01^{\mathrm{a}}$ & $61,56 \pm 5,59^{\mathrm{b}}$ & $47.46 \pm 0,57^{\mathrm{c}}$ & $40.90 \pm 4.05^{\mathrm{d}}$ \\
4 & $48.19 \pm 4,90^{\mathrm{a}}$ & $55,98 \pm 4,38^{\mathrm{b}}$ & $39,15 \pm 1,86^{\mathrm{c}}$ & $30.32 \pm 2.56^{\mathrm{d}}$ \\
\hline
\end{tabular}

Different superscript letters show a significant difference $(\mathrm{P}<0.05)$

[9] stated that, it takes $50 \%$ of the living spermatozoa to be continued at the IB stage. Referring to this provision, only P1 treatment can continue at the IB stage on the fourth day, while P0 treatment can be used on the third day, P2 on the second day and P3 treatment can only be used on the first day of storage.

The results of statistical analysis showed that the viability of spermatozoa in SO bulls on the ${ }^{4 \text { th }}$ day of storage showed a significant difference $(\mathrm{P}<0.05)$ between treatment $\mathrm{P} 0, \mathrm{P} 1, \mathrm{P} 2$, and $\mathrm{P}$ 3. Nonetheless, the low value of the viability of the semen of SO in P2 and P3 treatments was caused by the possibility that the percentage of palmyra palm juice in the diluent was too high because the palmyra palm has an acidity level if stored for more than 24 hours, as a result it also affects the viability value of SO Bulls. The measurement results of the acidity level decreased from the initial pH of 6.8 to 5.8 . Simultanously, [11] reported that a decrease in viability could occur due to cold temperatures, reduced energy availability in the diluent and decreased $\mathrm{pH}$ due to an increase in lactic acid metabolism, damage to the plasma membrane, and acrosome. Conversely, [3] stated that the decrease in the quality of spermatozoa was influenced by the increase in the duration of storage of spermatozoa nutrients in the diluent also decreased.

\section{Conclusion}

The addition of palmyra palm juice did not affect the motility of spermatozoa, but had a positive effect on the viability of spermatozoa with the addition of $5 \%$ palmyra palm juice storage for 4 days at a temperature of $3-5{ }^{\circ} \mathrm{C}$

\section{Acknowledgments}

Our gratitude to DRPM - Kemenristekdikti who has funded all funding for Beginner Lecturer Research activities for the 2020 funding.

\section{Reference}

[1] Azzahra, F.Y, Setiatin, E.T, dan Samsudewa, D, "Evaluation of Sperm Motility and Viability of Fresh Semen of Kebumen PO Bulls," Jurnal Sain Peternakan Indonesia, vol 11, no. 2, pp. 99-107, 2016.

[2] Affandhy L., Luthfi M., Ratnawati D., Firdaus F, "The Effect of Moringa oleifera (MO) Leaf Powder on the Quantity and Quality of Semen of Ongole Crossbreed," Jurnal of Tropical Animal Science and Technology, vol 7, no. 2, pp. 119-127, 2020. 
[3] Danang D., Isnaini N., dan Trisunuwati P, "The Effect of Storage Time on Native Chikens Spermatozoa Quality by Ringer Solution Diluent in $4{ }^{\circ} \mathrm{C}$ Temperature, "Jurnal Ternak Tropika, vol. 13, no.1, pp. 47-57, 2012.

[4] Fatkhul Mubin, M., Zubaidah, E., Kunci, K, "Studi Pembuatan Kefir Nira Siwalan (Borassus flabellifer 1.) (Pengaruh Pengenceran Nira Siwalan dan Metode Inkubasi)," Jurnal Pangan dan Agroindustri, vol. 4 no.1, pp. 291-301, 2016.

[5] Garner DL, Hafez ESE, "Spermatozoa and Seminal Plasma. Reproduction In Farm Animal 7th Eds. Edited By Hafez ESE, Hafez, B. Baltimore," Lippincott \& Williams, ed. 7, pp. 96- 109, 2008.

[6] Hafez ESE, Hafez B, "Preservation and Cryopreservation Of Gamete And Embryos. Reproduction In Farm Animals. 7th Eds. Edited By Hafez ESE, Hafez, B. Baltimore," Lippincott Williams and Wilkins ed. 6, pp. 82-95, 2008.

[7] Heriyanta E., Ihsan M. N., Isnaini N, "Pengaruh Umur Kambing Peranakan Etawa (PE) Terhadap Kualitas Semen Segar," Jurnal Ternak Tropika, vol. 14 no.2, pp. 1-5, 2013.

[8] Ismaya, "Bioteknologi Inseminasi Buatan pada Sapi dan Kerbau," Yogyakarta, Gadjah Mada University Press, 2014.

[9] Kusumawati E. D, Krisnaningsih A. T. N, Ramadlon R. R, "Kualitas Spermatozoa Semen Beku Sapi Simental dengan Suhu dan Lama Thawing yang Berbeda," Jurnal Ilmu-Ilmu Peternakan, vol. 26, no. 3, pp. 38-41, 2016.

[10] A Kusumawati E.D, Betu H, Krisnaningsih A.T.N, Rahadi S, "Kualitas Semen Segar Sapi Limousin Pada Lama Simpan yang Berbeda" Jurnal Ilmiah Fillia Cendekia, vol. 3, no. 1, pp. 19, 2018.

[11] A Pareira G. R., Becker E. G., Siquiera L.C., Ferreira R., Severo C. K., Truzzi V. S., Oliveira J. F. C. and Goncalves P. B. D, "Assessment Of Bovine Spermatozoa Viability Using Different Cooling Protocols Prior To Cryopreservation," Italian Journal Of Animal Science, vol. 9, pp. 403407, 2010.

[12] A Pubiandara S., Suharyati S., Hartono M, "Pengaruh Penambahan Dosis Rafinosa dalam Pengencer Sitrat Kuning Telur Telur terhadap Motilitas Persentase Hidup dan Abnormalitas Spermatozoa Sapi Ongole," Jurnal Ilmu Peternakan Terpadu, vol. 4, no.4, pp. 292-299, 2016.

[13] A Rahmawati M. A., Susilawati T., Ihsan M. N, "Kualitas Semen dan Produksi Semen Beku pada Bangsa Sapi dan Bulan Penampungan yang Berbeda," Jurnal Ilmu-Ilmu Peternakan, vol. 25, no. 3, pp. 25-36, 2014.

[14] A Sukmawati E, R.I Arifiantini dan B Purwantara, "Daya Tahan Spermatozoa terhadap Proses Pembekuan pada Berbagai Jenis Sapi Pejantan Unggul," Jurnal Veteriner, vol. 19, pp. 168-175, 2014.

[15] A Sulistyowati D., Faris M. A., Yekti A. P. A, “Kualitas Semen Cair Sapi Peranakan Ongole pada Pengencer Tris Aminomethane Kuning Telur Tanpa Raffinose yang Disimpan Pada Media yang Berbeda Suhu," Jurnal Ternak Tropika, vol. 19, no. 1, pp. 38-45, 2018.

[16] A Susilawati, T, "Tingkat Keberhasilan Inseminasi Buatan dengan Kualitas dan Deposisi Semen yang Berbeda pada Sapi Peran-Akan Ongole," Jurnal Ternak Tropika, vol. 12, no. 2, pp. 15-24, 2011.

[17] A Susilawati, "Pedoman Inseminasi Buatan Pada Ternak," UB Press, Universitas Brawijaya, 2013. 